\title{
The Influence of Leadership Style and Organizational Climate on Work Relationship
}

\author{
La Saafi ${ }^{1}$, Murdjani Kamaluddin ${ }^{2}$, Adnan Hakim ${ }^{3}$, Ansir $^{4}$ \\ ${ }^{1}$ Doctoral Program of Management Science, Halu Oleo University Kendari \\ Southeast Sulawesi, Indonesia \\ ${ }^{2,3,4}$ Faculty of Economics and Business. Halu Oleo University, Southeast Sulawesi, Indonesia
}

\begin{abstract}
The purpose of this study was to determine and analyze the influence of Leadership Style and Organizational Climate on Work Relationship. Collecting data used quetionaire. Sampling method used proportionate cluster random sampling. The sample was partially of Private University in Southeast Sulawesi and the sampled respondents were middle-level managers (Dean and Vice Dean), manager of the lowest level (LPPM, LPMI, Department, Study Program, BAAK, Library and Laboratory), and organizing committee (faculty and staff), as well as students. The numbers of samples in this study were 350 respondents. Method of data analysis used Partial Least Square (PLS). The results showed that of Leadership Style has positive and significant influence on Employment Relationship. Organizational Climate has positive and significant influence on Work Relationship. Leadership Style has positive and significant influence on Organizational Climate.
\end{abstract}

Keywords: Leadership Style, Organizational Climate, Work Relationship.

Date of Submission: 10 November $2016 \longrightarrow$ Date of Accepted: 05 December 2016

\section{INTRODUCTION}

The developments of human resources quality and productive through education are responsibility of Government and also community. Law of the Republic of Indonesia No. 20 of 2003 on National Education System in article 55, among others mentioned that the public right to conduct formal and informal education. As a form of community participation in education, the community can establish the Foundation as a legal entity which covers the institutions. The Foundation is a legal entity consisting of wealth separated and destined to achieve certain goals in the areas of social, religious, and humanitarian, which has no members. To achieve his aim foundations can establish business entities and / or participate in a business entity (UU-RI: No. 16, 2001). Nevertheless, the foundation remains a legal entity that is non-profit The performance assessment is a series of activities to evaluate the organization and competence of employees, improved performance and distribution of rewards (Flecher, 2001: 473). Development of performance assessment approach can be applied in the field of education if desired changes are focused on accountability (Fink, 2003). To reduce stress and facilitate effective performance, managers must demonstrate adequate leadership behaviors (Bass \& Riggio, 2006; Burke, 2002). This means to achieve the desired performance then a leader must be able to create conducive working environment and working relationship harmonies.

Rota et al (2013) have formulated the hypothesis that there is a positive relationship between sustainability performance sustainabilityy working relationships with the organization. Labor relations, can be defined as the relationship between the parts or individuals, both of them in the organization as well as between them and the parties outside the organization as a result of implementation of tasks and functions of each in achieving the goals and objectives of the organization (Kadarmo et al, $2001: 10$ ). Working relationship in this research is the working relationship between subordinates, and between subordinate to the leadership within the scope private University organization, and work realationship between private Universities with foundation. Rota, et al. (2012) have examined about the factors that affect the relationship of workers and employers (micro level), as well as the effectiveness and performance of the organization as a whole (macro level), and found a very good relationship between the variables studied, especially between organizational climate sustainability organization's relationship with staf. They advised to adopt a model that can be used in organizations and orthers countries. But because only one organization studied it is difficult to generalize.

Fynes et al. (2008) found that the quality of labor relations in a positive impact on performance, and suggested that future studies focus on the impact of another moderator variable between the quality of working relationships and network performance. Ernawati and Ambarini (2010) also found that the work relationship variables had significant influence on employee performance. In addition, the working environment has an 
influence on employee performance. Shonghari et al (2013) found that relationship quality dimension 'supply chain' examined included trust, adaptation, communication and collaboration on affect the quality of performance. Similarly, Carter et al. (2012) found the quality of the working relationship is so important for the organization incremental changes that can continuously encourage the employees' perception of the integrity of the attitude of managers thus realizing improved performance. Meanwhile, the results of research Rota et al (2012) indicates that there is a relationship between organizational climate and the sustainability of the work relationship are advised to develop a model that can be applied to other types of organizations and countries.

According to experts, the inadequacy of the agency theory can be overcome by adopting an approach of 'meso' to explain the role of each element in bridging, or linking, proposition between micro and macro levels of a form of organizational behavior analysis. In the literature there are several theories that combine both organizational phenomena (macro) and behavior (micro) - (R.House, et al., 1995). But only a few empirical studies were watching the role of organizational climate as a variable link between micro and macro analysis. Organizational climate plays a central role as a determinant of organizational behavior, by identifying how members should interact with each other and how to manage personal relationships. Thus, it can be hypothesized that organizational climate was the main liaison between the micro and macro levels of a form of organizational behavior (Rota, et al., 2012)Organizational climate is a set of characteristics that describe an organization that distinguishes between organizations with each other and influence the behavior of people in the organization (Farooqui, 2012: 296) .

Organizations climate try to identify environments that influence the behavior of employees (Holloway, 2012: 13) organizational climate approach will play a central role as a determinant of organizational theory, by identifying how its members can interact with each other and how to manage personal relationships (R.Harrison, 1992). However, few empirical studies on the role of organizational climate (R.House, et al., 1995) .Rota, et al. (2012) have examined the role organizational climate as a determinant of behavior and organizational success. They found there was a very good relationship between all the variables in the model, especially between innovation, trust, communication and sustainability of employment. The relationship between organizational climate on leadership behavior already many well-documented in the literature, namely climate leadership behaviors affect the organization (Fiedler, 1967; Field \& Abelson, 1982; Halpin, 1966; Muchinsky, 1977; Owens, 1981). Snyder (1990), has conducted research on the interrelationships between the behavior of the leadership, organizational climate and job satisfaction. Many research results that found an association between leadership and organizational climate (Noor \& Dzulkifli, 2013; McMurrray et al. 2010). But Ngadiman, et al (2013) found no significant correlation between transformational leadership the organizational climate in college, but no correlation with job satisfaction.

Leadership is the ability to instill confidence and the support of members of the organization to achieve organizational goals (Durbin, 2001). This means, the leadership can determine the success or failure of an organization (Thoha, 2004: 32). The same opinion also states that the leader has a great influence on the organization's success in meeting the challenges (Shein, 1992: 46). This shows that the leadership paint the entire process happens in an organization to achieve its objectives. Although the leadership of the PTS is not exactly the same as the organization in general, but PTS requires appropriate leadership style to achieve optimal organizational performance.

Leadership style as a manifestation of behavior in the form of a specific pattern of a leader, which concerns his ability to lead (David and Newstrom, 1996). Study about leadership style and performance have been done, including by Wilderom and Van den Berg (2000), Gani (2006), Purvanova et al. (2006), Widagdo (2006), and Brahmasari and Suprayetno (2008), as well as Pituringsih (2011). Ojokuku et al. (2012) found no correlation between the positive and negative dimensions of the type of leadership with organizational performance. They found no effect of leadership style on performance. Therefore, it is imperative PTS as nonprofit organizations need to implement an effective leadership style that can improve organizational performance.

\section{LITERATURE REVIEW}

\section{Work relationship}

In a company, the work relationship is defined as the relationship between workers and employers that occurred after the agreement held by workers with employers. Workers expressed his readiness to work on a wage employers, while employers expressed his readiness to to hire workers by paying wages (as specified in the employment agreement). Employment agreements contain provisions relating to the work relationship, the rights and obligations of workers and the rights and obligations of employers (Sumanto, 2014: 196).The working relationship occurs because of the labor agreements between employers and workers / laborers (UU-RI, 2003: art. 50). In addition, the company also known as industrial relations is the relationship between all the relevant parties or interest in the production process or services in an enterprise (Sumanto, 2014: 262). 
Fischer et al (2010) stated that there are four dimensions of the working relationship of confidence, commitment, satisfaction, and collaboration history that could explain the continuity of employment (relationship) organization. This suggests that in order to create a conducive working relationship organization with the necessary mutual trust between each other, a strong commitment to the organization, their job satisfaction, and a history of harmonious collaboration. In this study, the dimensions of the work relationship include trust, commitment, satisfaction, and collaboration history, like the research C.Rota et al (2012). In subsequent studies, C.Rota et al (2013) has formulated a hypothesis about the importance of the sustainability of the employment of the sustainability performance of the organization.

\section{Organizational climate}

In modern economic theory and organizational theory approaches there are two types of approaches, micro and macro approaches. Macro approach focuses on the factors that influence the effectiveness and performance of the organization as a whole, such as the organizational context, culture, climate and resource management (B. Schneider, et al., 1995 and B. Staw \& R. Sutton, 1993). Micro approach was watching the factors that affect the relationship at the level of individuals or groups such as motivation, attitude and performance of individuals or groups, while the macro approach does not effectively noticed internal processes and relationships that affect the organization's vision, growth and adaptation to environmental changes ( R.House, et al., 1995).Zeith et al (1997) suggest organizational climate consists of five interrelated dimensions, which is a challenging job, trust, innovation, social cohesion and communication. To create a conducive organizational climate necessary to have an interesting and challenging job, lack of mutual trust in the organization, the creation of conditions that enable the development of new innovations, their social cohesion and effective communication.

\section{Leadership style}

Leadership style as an embodiment of a leader's behavior regarding his ability to lead. The embodiments usually form a certain pattern (Davis and Newstrom, 1996: 69). One theory emphasizes a change in the most comprehensive and deals with the theory of leadership are transformational and transactional leadership (Bass and Avolio, 1990: 1).

\section{Leadership Style with the Employment Relations and Organizational Climate}

Snyder (1990), has conducted research on the interrelationships between the behavior of the leadership, organizational climate and job satisfaction. Many research results that found an association between leadership and organizational climate (Noor \& Dzulkifli, 2013; McMurrray et al. 2010 and 2012). Esraghi et al (2011) in their study of the relationship of organizational climate and leadership style of physical education office manager, found a positive correlation between organizational climate (objectives, roles, awards, procedures, and communications) with the leadership style of managers. However, Ngadiman, et al (2013) found no significant correlation between leadership transformational the organizational climate in college, but no correlation with job satisfaction. Then, Omolayo et al. (2012) stated that the leadership style and organizational climate on job satisfaction, but did not find a significant relationship between job satisfaction and leadership style.McMurray et al. (2010) have examined the effect of leadership on organizational climate, employee psychological capital, commitment and happiness in a church / religious-based non-profit organization. They found that there is a strong positive relationship between employee ratings on transformational leadership with immediate supervisors and employees on organizational climate assessment, happiness, employee commitment and psychological capital. This study provides a significant contribution to non-profit organizations by providing clues about the impact of leadership on organizational climate.

\section{CONCEPTUAL FRAMEWORK}

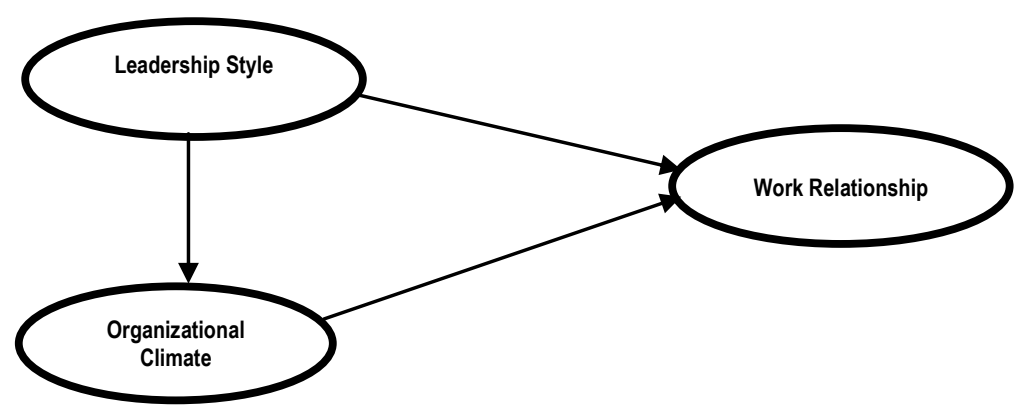




\section{METHOD}

The sample was partially of Private University in Southeast Sulawesi and the sampled respondents were middle-level managers (Dean and Vice Dean), manager of the lowest level (LPPM, LPMI, Department, Study Program, BAAK, Library and Laboratory), and organizing committee (faculty and staff), as well as students. The numbers of samples in this study were 350 respondents.

The data analysis technique used to test the hypothesis is Partial Least Square (PLS) path modeling, using a program SmartPLS 2.0. The advantages of this method compared to the PLS analysis of covariance structures such as LISREL, EQS, Mplus or AMOS, is PLS does not require a large sample and the assumption of normality. In addition PLS-SEM can easily handle reflective measurement models and formative, CONSTRUCTS one item, without causing a problem identification (Fornell, C and Bookstein, F L., 1982; Bacon, L D., 1999; Hair, JF , at al., 2014).

\section{RESULT}

Table 1. Estimated Results of Loading Factor

\begin{tabular}{|l|l|l|l|}
\hline \multirow{2}{*}{ Construct } & Dimension & $\begin{array}{l}\text { Factor } \\
\text { Loading }\end{array}$ & t-value \\
\hline \multirow{2}{*}{ Leadership Style } & $\mathrm{X} 1.1$ & 0.932 & 119.663 \\
\cline { 2 - 4 } & $\mathrm{X} 1.2$ & 0.739 & 14.000 \\
\hline Organizational Climate & $\mathrm{X} 2.1$ & 0.810 & 30.535 \\
\cline { 2 - 4 } & $\mathrm{X} 2.2$ & 0.764 & 18.161 \\
\cline { 2 - 4 } & $\mathrm{X} 2.3$ & 0.851 & 48.999 \\
\cline { 2 - 4 } & $\mathrm{X} 2.4$ & 0.750 & 19.194 \\
\hline \multirow{3}{*}{ Work Relationship } & $\mathrm{Y} 1.1$ & 0.897 & 78.998 \\
\cline { 2 - 4 } & $\mathrm{Y} 1.2$ & 0.871 & 0.854 \\
\cline { 2 - 4 } & Y1.3 & 0.893 & 55.604 \\
\cline { 2 - 4 } & Y1.4 & 70.353 \\
\hline
\end{tabular}

Description: $\mathrm{X} 1.1=$ Transformational, Transactional $=\mathrm{X} 1.2, \mathrm{X} 2.1=$ Confidence, $\mathrm{X} 2.2=$ Challenge tasks, $\mathrm{X} 2.3$ = Innovation, X2.4 = Social Intimacy, Y1.1 = Confidence, Y1.2 = commitment, Y1.3 =Satisfaction, Y1.4 = Collaboration

Table 2 shows the convergent validity were acceptable. No more observed variables (dimensions) should be eliminated because all have loading > 0:50 and significant at the 5\% significance level (t-value $>1.95$ ).

While the value AVE is presented in Table 3

Table 2. Estimated Results Average Variance Extracted (AVE)

\begin{tabular}{|l|l|l|}
\hline Construct & $\boldsymbol{A} \boldsymbol{E}$ & Description \\
\hline Leadership Style & 0.707 & Valid \\
\hline Work Relationship & 0.772 & Valid \\
\hline Organizational Climate & 0.632 & Valid \\
\hline
\end{tabular}

Discriminant validity of evaluation is based on the analysis of cross-loadingdan Average Variance Extracted (AVE). The estimation results of cross-loading each construct are presented in the following table.

Table 3. Matrix Cross-Loading

\begin{tabular}{|l|l|l|l|}
\hline Dimension & Leadership Style & Work Relationship & Organizational Climate \\
\hline X1.1 & $\mathbf{0 . 9 3 2}$ & 0.652 & 0.733 \\
\hline X1.2 & $\mathbf{0 . 7 3 9}$ & 0.298 & 0.438 \\
\hline X2.1 & 0.600 & 0.549 & $\mathbf{0 . 8 1 0}$ \\
\hline X2.2 & 0.508 & 0.539 & $\mathbf{0 . 7 6 4}$ \\
\hline X2.3 & 0.720 & 0.661 & $\mathbf{0 . 8 5 1}$ \\
\hline X2.4 & 0.458 & 0.635 & $\mathbf{0 . 7 5 0}$ \\
\hline Y1.1 & 0.563 & $\mathbf{0 . 8 9 7}$ & 0.725 \\
\hline Y1.2 & 0.519 & $\mathbf{0 . 8 7 1}$ & 0.646 \\
\hline Y1.3 & 0.479 & $\mathbf{0 . 8 5 4}$ & 0.571 \\
\hline Y1.4 & 0.578 & $\mathbf{0 . 8 9 3}$ & 0.686 \\
\hline
\end{tabular}


Based on the table above, the loading factor of each dimension on the factors that should be measured more compared cross-loading it on another factor. Meanwhile, according to Fornell-Larcke criteria, the estimated value of the correlation coefficient between pairs of constructs and the square root of the AVE (SQRT of AVE) are presented in the following table.

Table 4. Latent Variables and Correlation MatrixSquare Root value AVE (SQRT of AVE)

\begin{tabular}{|l|l|l|l|l|}
\hline Construct & $\begin{array}{l}\text { Leadership } \\
\text { Style }\end{array}$ & $\begin{array}{l}\text { Work } \\
\text { Relationship }\end{array}$ & $\begin{array}{l}\text { Organizational } \\
\text { Climate }\end{array}$ & $\begin{array}{l}\text { SQRT } \\
\text { of AVE }\end{array}$ \\
\hline Leadership Style & 1.000 & & & 0.841 \\
\hline $\begin{array}{l}\text { Work Relationship } \\
\text { Organizational }\end{array}$ & 0.611 & 1.000 & & 0.879 \\
\hline \begin{tabular}{l} 
Climate \\
\hline
\end{tabular} & 0.729 & 0.752 & 1.000 & 0.795 \\
\hline
\end{tabular}

According to the table above, it appears that all the correlations between pairs of constructs is smaller than the square root of the AVE, which shows the fulfillment of discriminant validity. Evaluation Measurement Reliability Evaluation of reliability using composite reliability. Results composite reliability estimates are presented in the following table.

Table 5. Composite Reliability Estimation Results

\begin{tabular}{|l|l|l|}
\hline Construct & $\begin{array}{l}\text { Composite } \\
\text { Reliability }\end{array}$ & Description \\
\hline Leadership Style & 0.827 & Reliable \\
\hline Work Relationship & 0.931 & Reliable \\
\hline Organizational Climate & 0.873 & Reliable \\
\hline
\end{tabular}

Based on the table above, the estimation of reliability showed good results for the value composite reliability of each construct has met the required rules of thumb that is $>0.6$. Thus it can be said that all the constructs totally reliable means of measurement models have been met Estimation and Evaluation of Structural Model. The results of path coefficient estimates the effect of a construct to construct another, with 2.0 SmartPLS program, presented in the table and figure below.

Table 6. Estimation Results Relationships between Constructs

\begin{tabular}{|l|l|l|l|l|}
\hline & & Coefisien & t-value & Description \\
\hline $\mathrm{H} 1 \mathrm{a}$ & $\mathrm{X} 1 \Rightarrow \mathrm{Y}$ & 0.611 & 17.645 & Significant \\
\hline $\mathrm{H} 1 \mathrm{~b}$ & $\mathrm{X} 1 \Rightarrow \mathrm{X} 2$ & 0.729 & 25.734 & Significant \\
\hline $\mathrm{H} 2$ & $\mathrm{X} 2 \Rightarrow \mathrm{Y}$ & 0.654 & 13.433 & Significant \\
\hline
\end{tabular}

Description: X1 = Leadership Style, X2 = Organizational Climate, Y = Work Relationship

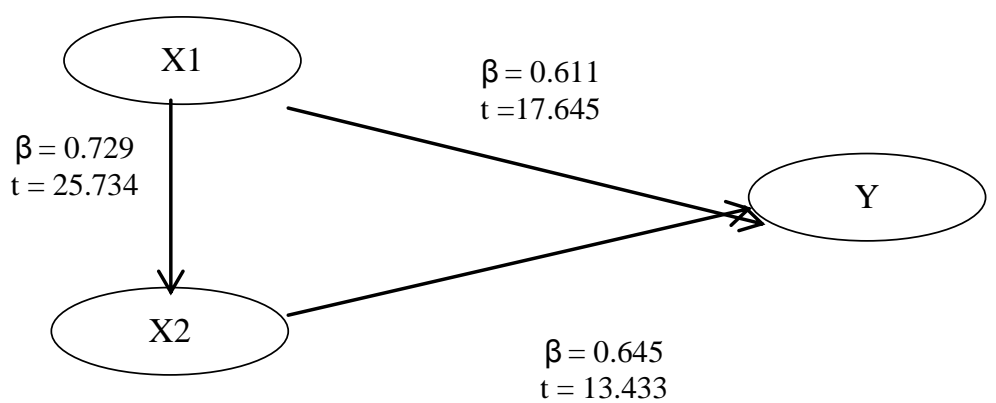

Figure 1. Relationships between Constructs Estimation Results

While the results of the statistical estimation Stone-Geiser R2 and Q2 to fit indeces are presented in the following table.

Table 7. Estimation Results R2 and Stone-Geiser Q2

\begin{tabular}{|l|l|l|}
\hline $\begin{array}{l}\text { Endogen/ } \\
\text { Dependen }\end{array}$ & $\mathbf{R}^{\mathbf{2}}$ & $\mathbf{Q}^{\mathbf{2}}$ \\
\hline Work Relationship & 0.574 & 0.432 \\
\hline Organizational Climate & 0.531 & 0.325 \\
\hline
\end{tabular}


Based on the value of R2 in the table above, shows that about $53.1 \%$ of climate changes in the organization can be explained by the variable of leadership style, and approximately $57.4 \%$ changes in labor relations is explained by two variables capable leadership style and organizational climate. Based on the valueGeiser Stone Q2 indicates that the model has predictive relevance, because both value greater than 0.1.2.1 Hypothesis 1: The Influence of leadership style on Work Relationship.

The estimation results of the influence of leadership style to employment relationships in Table 7 was obtained regression coefficient of 0611 (positive) and t ( $\mathrm{t}$-value) amounted to 17 645. the t-value> 1.96 means significant at the $5 \%$ significance level. So there is a positive and significant effect of leadership style on the employment relationship.1.2.2 Hypothesis 2: The Influence of Leadership Style on Organizational Climate.

The estimation results of leadership style influence the organizational climate in Table 7 obtained a regression coefficient of 0.729 (positive) and t (t-value) amounted to 25 734. t-value $>1.96$ means significant at the $5 \%$ significant level. So there is a positive and significant effect of leadership style on organizational climate.1.2.3 Hypothesis 3: The Influence of Organizational Climate on Work RelationshipThe estimation results of climate influence the organization of their working relationship in Table 7 was obtained regression coefficient of 0654 (positive) and (t-value) amounted to 13433 . t-value> 1.96 means significant at the 5\% level. So there is a positive and significant impact on the organizational climate of

\section{CONCLUSION}

Based on the results of research and discussion it can be concluded that: Leadership Style has positive and significant influence on Work Relationship. Organizational Climate has positive and significant influence on Work Relationship. Leadership Style has positive and significant influence on Organizational Climate.

\section{REFERENCES}

[1] Bass, B,M, 1994. Improving Organizational Effectiveness through Transformational Leadership, Leading Organizational Perspective for New Era, New Delhi. California

[2] Bass, B..M. danAvolio, B.J. 1990a. Transformational Leadership Development Manual for the Multifactor LeadrshipQuesioner, Consulting Psychologist. Free Press, Palo Alto, CA

[3] ------. 1990b. From Transactional to Transformational Leadership: Learning to Share the Vision, Organization Dynamics, 18(3), p.1

[4] Bass, B. M., danRiggio, R. E. (2006). Transformational leadership. Mahwah, NJ: Erlbaum.

[5] Brahmasari, Ida Ayu, dan Agus Suprayetno. 2008. Pengaruh Motivasi Kerja, Kepemimpinan, dan Budaya Organisasi terhadap Kepuasan Kerja Karyawan serta Dampaknya pada Kinerja Perusahaan, Jurnal Manajemen dan Kewirausahaan, 10(2):124-125.

[6] David, Keith and John W.Newstrom, 1996. Human Behaviour at Work OrgananizationBehaviour, Fifth Edition, New Delhi: Mc.Graw Hill Publishing Ltd., p. 69.

[7] Ernawati dan Ambarini. 2010. Pengaruh hubungan kerja dan lingkungan kerja terhadap kinerja pegawai dengan motivasi kerja sebagai variable moderating, JurnalEkonomidanKewirausahaan, Vol. 10, No.2 halaman 100-112, Oktober 2010.

[8] Farooqui. M.R. 2012. Measuring Organiation Citizenship Behaviour (OCB) as a Consequence of Organization Climate (OC), Asian Journal of Business Management, Vol. 4 No.3 p. 294-302.

[9] Fischer, C.; Hartmann, M; Reynolds, N.; Leat, P.; Revoredo-Giha, C.; danHenchion, M. 2010. Factors Influencing Contractual Choice and Sustainable Relationship in European Agri-food Supply Chains, European Review of Agricultural Economics, 36, (2010), 541-569.

[10] Fiedler, F. (1967). A theory of leadership effectiveness. New York: McGraw-Hill.

[11] Field, R., \& Abelson, M. (1982). Climate: A reconceptualization and proposed model.Human Relations, 35, 181-201.

[12] Fynes, Brian; Sean de Burca, and John Mangan. (2008). The Effect of Relationship Characteristics on Relationship Quality and Performance, International Journal of Production Economics, 111(1): pp. 5659, Elsevier

[13] Fink, D. (2003), "The law of unintended consequences: the 'real' cost of top down reform", Journal of Educational Change, Vol. 4 No. 2, pp. 105-28.

[14] Fletcher, C. (2001), "Performance appraisal and management: the developing research agenda",Journal of Occupational and Organizational Psychology, Vol. 74 No. 4, pp. 473-87.

[15] Gani, Achmad. 2006. Pengaruh Gaya Kepemimpinan, Budaya Organisasi dan Motivasi Kerja terhadap Kinerja. Disertasi Program Doktor, Universitas Brawijaya, Malang.

[16] Halpin, A. (1966). Theory and research in administration. New York: Macmillan.

[17] Kadarno, SiwiUltima, dkk. 2010. Koordinasi dan Hubungan Kerja, Lembaga Administrasi Republik Indonesia, Jakarta. 
[18] Muchinsky, P. (1977). An assessment of the Litwin and Stringer questionnaire. PersonnelPsychology, 29, 371-392

[19] Noor, Haris M, and Bari'ahDzulkifli. 2013. Assessing Leadership Practices, Organizational Climate and Its Effect towards Innovative Work Behaviour in R\&D, International Journal of Social Science and Humanity, Vol. 3 No. 2, March 2013

[20] Pituringsih, Endar. 2011. Pengaruh Gaya Kepemimpinan dan Budaya Organisasi terhadap Kinerja Organisasi dengan Penerapan Good Governance sebagai Variabel Moderasi (Studi Empiris pada Perguruan Tinggi Swasta di JawaTimur), Disertasi Program Doktor, Universitas Brawijaya, Malang.

[21] Purvanova, R.K., Joice E.B., and Jessica Dziewecynksi. 2006. Transformational Leadership, Job Charcteristics, and Organizational Citizenship Performance, Journal of Human Performance, 19(1):1-22.

[22] Shonghari, M. Alizadeh; Solaiman Iranzadeh, and Kamal Khalipour. 2013. The impact of supply chain relationship quality on quality performance (Case study: Sugar Factory of Naghadeh city), International Research Journal of Applied and Basic Sciences., Vol. 6 (9): 1229-1233.

[23] Schein, E.H. 1992. Organizational Culture and Leadership, $2^{\text {nd }}$ Edision, Jossey-Bass San Francisc

[24] Sumanto. 2014. Hubungan Industrial: Memahami dan Mengatasi Potensi Konflik-Kepentingan Pengusaha-Pekerja pada Era Modal Global, Penerbit Center of Academic Publishing Service (CAPS), Yogyakarta.

[25] Thoha, Miftah. 2004. Kepemimpinan dalam Manajemen: Suatu Pendekatan Perilaku, Cetakan Ketujuh, Jakarta: Raja Grafindo Persada.

[26] Widagdo, Bambang. 2006. Pengaruh Faktor Karismatik Individudan Kepemimpinan terhadap terhadap Budaya Organiasi, Manfaat Kehudupan Kerja serta Kineja Dosen pada Perguruan Tinggi Muhammadiyah di JawaTimur, Journal of Business and Management, 5(3):547-567.

[27] Zeith, G.; Johannesson, R; dan Ritchie, J.E. 1997. An Employee Survey Measuring Total Quality Management Practices and Culture: Development and Validation, Group Organization Management, 22, (1997), 414-444. 